\title{
Emerged Apartheid in Colonial South Africa: A Critical Commentary on Rosa Burger's Experience of Her Private Life and Public Life in Burger's Daughter by Nadine Gordimer
}

\author{
Rashid, A.K.M. Aminur \\ Assistant Professor- Department of Languages- College of Arts and Sciences- IUBAT- International \\ University of Business Agriculture and Technology- Bangladesh \\ akmaminur.rashid@iubat. edu
}

\begin{abstract}
In her novel, Burger's Daughter, Nadine Gordimer (1923) treats the theme in the light of the historic apartheid movement in the then South Africa. The novel primarily focuses on how the black race got severely segregated from the white race in terms of rights in the same land. The novel presents its protagonist, Rosa Burger, who is, actually, the writer's mouthpiece. Rosa wants to put an end to the totalitarian system dreaming of a free South Africa that undertones Gordimer in its fullest. In this process, Rosa has to go through her experiences of being public from her private life. She waits in the line to meet her parents outside the jail, where her parents are kept captivated. She realizes the feeling being "The Other" in her own land because her parents are arrested for their being on the anti-apartheid movement. Being a daughter of a political family, Rosa has also become public to help her parents. During her journey to free her parents, she also experiences the internal colonialism and corruption. Ultimately, she becomes a public figure, realizing the maltreatment she receives from the white Africans and developing her sentiment for the "Black Conscienceness" during the Apartheid hours.
\end{abstract}

Keywords: Apartheid, Bildungsroman, Subjectivity, Private and Public Life, Colonialism.

\section{Introduction}

You see, writing for me is not a political activity. Before anything else, I am a writer. But because the society in which I live is so permeated with politics, my work has become intimately connected with the translation of political events, of the way politics affect the lives of people. I imagine that the South African government considers me a political adversary - as if I were someone utilizing my profession to combat it. But I myself would not call what I do a political activity, because even if I lived elsewhere, I would still be a writer.

- Nadine Gordimer, 1979 (Servan-Schreiber, 108).

Nadine Gordimer was born at Transvaal in South Africa in 1923. She extensively dedicates her life to writing regarding South African issues, that is to say, apartheid, racial prejudices and colonialism. Her Burger's Daughter constantly focus on South African political issues and segregation in its nation. As noted by the critics, Ileana Dimitriu (2016) says that this novel "bears the marks of politically "overdetermined' times" (p. 1046) She becomes the mouthpiece of her society reflecting how the nation is torn between two identities, that is to say, the White and the Black. Her prolific writing about this socio-cultural politics is relevant Burger's Daughter. This novel is a piece of work that remarks apartheid as a force of displacement that clarifies lacks of transculture in harmony. As claimed by Mikhail Epstein (2009),

Transculture cannot be described in positive terms, as a set of specifc cultural symbols, norms, and values; it always escapes defnition. It is an apophatic realm of the "cultural" beyond any specifc culture or cultural identity. ... It does not "have place" anywhere: it is a force of displacement (p. 332). 
In this novel, she presents a female character, Rosa Burger, whose father Lionel Burger is sentenced for he is involved in the anti-apartheid activities. After his death, Rosa is confronted with uncertainty of life and gradually begins to understand to survive in this estranged land of South Africa.

In short, Gordimer (1923) describes a journey of Rosa from innocence to experience. She is against the totalitarian government of South Africa and dreams of a free land. Through presenting the violence between two races, her works also convey a hint of redemption as a massage because she wants to bring an end to such violence and redeem humanity. She creates an intimate relationship with her people and believes in equal right of everyone. She realizes a sort of psychological detachment of her own people due to the racial conflict which creates territorialization in the same society, that is to say, the White territory and the Black territory. For her narrative technique, Gordimer (1923) is considered to be a great artist of her time and can also be considered as a representative literary figure in African literature for her transcultural novel. Arianna Dagnino (2015) defines,

A novel whose main characteristic includes the creation, recreation, and interweaving of diverse cultural landscapes through which the writer and readers are able to see things from a diferent perspective and through which empathic and mental states of proximity and interconnectedness are being generated (p. 202).

\section{Tradition of Bildungsroman}

Bildungsroman is the term used in the African novels, which at the same time implies a historical account in a story. In Burger's Daughter, the author narrates Rosa Burger's life but her life also connects the historical apartheid in South Africa. Gordimer (1923) prepares a fictional story of her and shows how she develops a political idea and thus combines both private and public life in her character. She is Conrad's beloved, but at the same time a growing political figure. Bildungsroman is actually a literary tradition in which the authors are identified playing double roles. For example, Nadine Gordimer (1923), Ngugi Ngũgĩ wa Thiong'o (1938), Nuruddin Farah (1945) and many of the other are artists and at the same time critics who not only narrate stories but also find out the social illnesses and inform the readers. They use dialogue which is intensely engaged in its historical context, and their main characters convey political ideologies of their own and bring out the facts and the historical account.

\section{Influence of South African Apartheid on the Private Life of Rosa}

Nadine Gordimer's (1923) Burger's Daughter deals with the early years of apartheid in South Africa. As the novel unfolds, there is always a difference between the whites and the other casts according to the past records. Gordimer (1923) sees this kind of separation and territorialization in her own land, South Africa. Beck (2000) writes in "History of South Africa" that "Only White South Africans, however, were truly citizens. Asian, Coloreds and specially Africans might as well have lived in another world" (p. 101). In Burger's Daughter, Gordimer (1923) shows how Rosa's father suffers from being "Other" in his own land. He is an anti-apartheid activist who is caught by police several times and is finally sentenced. This word, "Other" is a significant term in literary uses. It indicates that being a failure to operate as a subject. In this respect, John Sturrock (1979) describes "The Other",

in each of its incarnations it is that which introduces 'lack' and 'gap' into the operations of the subject and which, in doing so, incapacitates the subject for selfhood, or inwardness, or apperception, of plentitude; it guarantees the indestructibility of desire by keeping the goal of desire in perpetual flight. (p. 134)

South Africa has then been a police state where blacks and other casts' have no voice except the White. This is the white government policies which are made to oppress the other casts and 
suitable for whites. Gordimer (1923) protests this and brings forth the idea of "privilege" and "ignorance". She tells through the third person voice that "the white people in general in our country, worship the God of justice and practise discrimination on grounds of the color of skin; profess the compassion of the Son of Man, and deny the humanity of the black people they live among" (p. 19). She notices the unlawful privileges the Whites are taking at the expense of the Blacks, who are defined to be the other from the Lacanian perspective. Rosa being a child of the black clan has also suffered from this sense of being the other. Her struggle to free her parents and to define an identity exemplify Lacan's reasoning of subjectivity what Lacan (1977) remarks "the discourse of the Other" (p. 285). Lacan pays attention to a person as subject in the society. Rosa's position as a subject raises an indication of lack leading to unconscious what from the Lacanian viewpoint is "discourse of the Other".

However, the novel opens with the girl, Rosa Burger, a fourteen year old girl waiting outside the prison to visit her father like others. The persons who are in prison are surely related to public matters and Rosa's waiting for visiting her father initially places her between public and private. In addition, Gordimer (1923) very tactfully juxtaposes Rosa's private life with the public because the author's third person voice presents her as a "school girl" which is private, but the family, from where she comes has a strong political background. Her father's sentence traces the significance of the South African domination over other casts. After winning the general election, the South African party is confronted with some new general issues. The party has to consider some important issues such as a new form of government, job facilities, racial discriminations and the internal problems in South Africa. But the party installs dominion over the internal affairs of the South Africa. They retain the domination over the blacks as they think that the blacks are the inferior race. In this regard, Pramod K. Nayar (2013) can be quoted to deepen Rosa's experiences. Rosa'a situation is complicated owing to the class struggle and racial tension, which a white woman lacks because she emerges from the white dominance. Pramod K. Nayar (2013) is of the opinion that "One should not immediately assume that such writing ignores social and political problems in favour psychological explorations of the "women condition" (p. 118).

In fact, the way the white South African retains the power is the beginning of the internal colonialism and it becomes more intense when they take over the economy, job reservations and facilities. Lionel Burger observes this privilege of the whites as the direct oppression on the blacks. In this way, Lionel Burger along with his wife finds themselves involved in the anti-apartheid movement. Rosa's responsibility increases after her parents are arrested. She takes care of them and supports their anti-apartheid behavior. In this case, Gordimer (1923) finds out an internal link between Rosa's personal life and her parents' public politics. When her parents are in distress in jail, she rushes to them, which signifies her growing sympathy towards her parents. As a result, her personal life is dedicated to her parents who are the political personnel and gradually Rosa also becomes publicly known. Describing Rosa's struggle, Karen Halil (1994) assimilates,

Her journey is an arduous one, for she must establish her textual flexibility not only between the oppositions of personal and political discourses, but also between the complex network of political discourses which construct her. As an Afrikaner woman she must explore race and gender; she must travel the world "round as a navel" to learn to be at "home" in her body as

a private woman and to find her "home" as a political subject in South Africa. (p. 32)

Moreover, the first section of the novel is the public explanation of Rosa's family and life while the second section moves to a more private life but interestingly both the sections are mixed with private and public. In this respect, Rosa's sympathy for her father who is in jail is her private feeling, but her feeling for him is also public because she also desires for a free South Africa which is political. Her parents' constant struggle against the apartheid makes life uncomfortable and uncertain not only for themselves but also for Rosa. Therefore, her private life completely turns to be public at the end. She wants to meet her half-brother in Northern Tanzania but "the administration knew who she was and would not give her permission to live in a black 'homeland"' (p. 31). Even 
her passport is seized and when Flora says to Rosa that "maybe they're in the mood to relent and give you a passport" Flora's husband reacts against her and shouts "Don't be absurd, Flora" (p. 33). Because of her father's becoming a public figure, she is also affected by it. Rosa's experience of private mixed with pubic encounters can be compared with the life of Warringa in Devil on the Cross and with Ebla in From a Crooked Rib. Like Rosa Warringa is also affected by Kenya's internal colonialism and corruption. Ngugi (1938) presents a horrifying picture of the contemporary Kenya, where, like South Africa, it gets involved in a conflict with its own nation.

In addition, he narrates a story of the colonial male race, which becomes dominant over the female race economically and politically. Warringa is confronted with the internal colonialism in Kenya, where women are considered as the "Other" like Lionel Burger. There is no job and political right for women in that time. The male oppression does not stop only depriving the female of their human right, but the women have to sacrifice their purity to earn livelihood. The author says that "The Modern Love Bar and Lounge has become the main employment bureau for girls, and women's thighs are the tables on which contracts are signed" (p. 19). Warringa's personality undergoes insult at this judgment of the male society. To survive in such society, she must surrender her body to Boss Kihara and she will become almost like a prostitute. This is the code by which women are ruled. Thus, in the internal colonial system in Kenya, many of the women like Warringa are brought into public and are deprived of privacy. Actually, in the world of business "private" and "public" are inseparable. Similarly, Ebla in From a Crooked Rib, written by Nuruddin Farah (2003) also fights for retaining her identity in the world of colonial administration. She has no way to escape, which means she is trapped in the world she lives in. Her private life is affected by the business world of Somalia. She asks herself "how to escape, where should she escape to, whom should she go" (p. 11). That severe condition of women is further realized when Rosa remarks in the novel,

But real awareness is all focused in the lower part of my pelvis, in the leaden, dragging, wringing pain there. Can anyone describe the forces in the menstruation of early puberty?

The bleeding began just after my father had the internal landscape of my body turns me inside out in that public place on that public physically I had one. (p. 16)

From a Marxist viewpoint, the exercise of colonial power always rests on humiliating others especially the weaker. Ebla's cousin gives her hand to a stranger only for some money as he tells her "the broker paid him some money for your hand. As dowry or something" (p. 70). This means that she is sold; sold like cattle. Therefore, the stories of Warringa and Ebla can be seen in the light of Rosa's life in the time of apartheid. Rosa cannot distinguish her private life from the public because she is Rosa Burger. She acknowledges that "I have no passport because I am my father's daughter. People who associate with me must be prepared to be suspect because I am my father's daughter" (p. 59). She suffers from this South African apartheid mostly and loses her privacy under public politics. This is an identity crisis promoted by the white Africans what in the words of Arianna Dagnino (2016), a power that "allows individuals to adopt new ways of self-identifcation" (Dagnino, 2016, p. 2)

\section{Rosa's Cultural Identity in Public and Her Private World}

In Burger's Daughter, the portrayal of "Cultural Identity" and the "Private World" are relevant in the characters of the novel especially in Rosa. In 1948, the apartheid in South Africa confuses human's private and public relationship. Although private and public should be separated but as M. Keith Booker (1998) argues that "many Marxist critics have seen the creation of a sense of separation between public and private life to be the central effects of capitalism and one of the crucial tools through which the bourgeoisie maintain their power in capitalist society" (p. 136). The capitalist attitude of the white South Africans creates a sense of cultural identity between the nation and, as a consequence, a conflict takes place in the country on the issue of racial identity and the government starts arresting and sentencing the protestors. Rosa's father is a political activist against 
this segregation and fragmentation. For his work against the socio-political segregation, he is taken into prison. But he leaves behind his daughter who doubts her free existence. She doubts if she has any privacy or if there is any private place for her. Her father is convicted and as his daughter, she is also suspected. She is treated in the way the Blacks, the Colourds and the Asians are treated. She is also considered to be "other" by the government. Being "Other" in the society, Rosa is seen to have no privacy. The denial of her privacy is the proof of her being public in general. She cannot go beyond her name which makes her "Other" because Lionel's blood runs through her veins. If her father is convicted, she is also same in this case. This is the idea of typification of which Lukacs says that "the great realist novelists achieve their connection between public and private realms primarily through the technique of "typicality"' (p. 136).

Rosa's father is the typical representative of the cultural apartheid of his time and thus, according to Lukacs, he embodies both private and public energies in a single figure. Rosa's being the daughter of Lionel Burger, who suffers and later dies in jail also means to have the same typical embodiment of both private and public in her 'being'. She is not only restricted in the country for being Rosa Burger rather for her being a typical representative of the Burger family by birth which cannot be reconstructed and changed. She says, "I am like my father- the way they say my father was. I discover I can take from people what I need" (p. 193). Her name does also typify her social position. For example, her first name, 'Marie' is taken from her grandmother's name, 'Marie' which is private, but the Surname, 'Burger' is taken from her father, a political activist which is public. Hence, her identity is fixed, that is to say, an identity she inherits will never be faded. Fats' wife introduces Rosa, telling "this is Lionel Burger's daughter" (p. 146). Everywhere, she is known by her father's name as if she had no personal existence or private identity. Nobody cares what she wants because everybody thinks that she should be like her father.

In Devil on the Cross Warringa's identity is also fixed as the "sugar girl" by the culture she lives in. She is used as if she were a product which a man purchases. The author of this novel wonders that the internal colonialism which is prevailing in Kenya does not regard women as human beings rather she is like a "new necklace" which is thrown away when the necklace becomes old. "Didn't I tell you one doesn't go to a dance wearing old scentless perfume? Kareendi, my new necklace" (p. 22). To use a woman as usable product is the very public matter in contemporary Kenya at that time and many of the young girls like Warringa feel trapped in that public affairs. In the Devil's feast, all of the members disclose their amount of money, brand new cars, girl friends and many of the others. Through their discourse, it can be understood that they are corrupt and oppressive. Ngugi's (1938) presentation of Warringa's social position results in the very colonial culture which disturbs individuality and private world. If a girl gets nude, she has a job, flat, car but on second thought, this happiness lasts as long as she is liked by her employer like Boss Kihara. Boss Kihara says to Kereendi who is Warringa herself "if you keep me happy with all earthly delights, I will buy you a small basket for the market, for shopping. I think an Alfa Romeo is the kind of car that would be fitting for a bride" (p. 22). The so-called money minded society destroys all internal affairs, personal values in Kenya rather it brings everything in public. The situation is created in such a way both in Kenya and South Africa that both Warringa and Rosa have no other way but remain in that world. Rosa says, "Lionel-my mother and father-people in that house, had a connection with Blacks that was completely personal. In this way, their communism was the antithesis of antiindividualism" (p. 138).

Therefore, the relation to blacks overthrows the Burgers along with Rosa from their white identity and imposes upon them a kind of more restricted form of life. Similarly, in From a Crooked Rib Farah (1945) portrays a similar restricted form of life for women like Ebla. She is seen to escape from her grandfather's house. Her grandfather wants to give her hand to an old man but she denies. She runs away from there, but she is again trapped in her cousin's house. From there she elopes with Awill, a young lover, but she is humiliated by him. She is seduced by him, though he marries her. Awill goes to Italy, living her behind. She makes a relation with an old man called Tiffo because she 
feels vulnerable being lonely. In this way, she cannot be a wife, but becomes almost like a prostitute. She says, "I wonder if I am a prostitute; I wonder how many people think that I am one" (p. 140). This is a patriarchal system in which she is used by men. The society Ebla lives in is colonized by patriarchy and women have been silenced. In this novel women's life is seen to have been shaped by men. The woman has nothing to do with whom she will marry and how she will behave. Similarly Ebla does not have any personal opinion. All she has to do is to follow the rules of patriarchy which is public. Although she escapes from her grandfather, she cannot do this all the time because everywhere there is a male for her. In the opening of part two of the novel Farah (1945) quotes from Samuel Beckett, "There's a man all over for you, blaming on his boots the faults of his feet" (p. 19). At last, she realizes that she can never escape any more. At the end of the novel she reconciles herself to Awill's sexual urge. Ebla's private feeling to be wife is fulfilled, but, at the same time, her social position as a weaker sex is also noticeable which is public.

In Burger's Daughter, Rosa grows watching her parents' constant struggle and matures watching her father's sentence and death. She experiences a fight between the non-whites who are weak and the whites who are strong. To retain the power, the whites even sentence a white man, Lionel Burger because he fights for the liberty of the blacks which is not possible in the bourgeois economic system of South Africa. Rosa also experiences that Katya leaves Lionel for another man because she finds out no future with that man since he can be arrested and sentenced to death any time. Rosa sees how Katya's private life is affected by Lionel's public affairs. He dies at last but Rosa dies every time since she still remains in the shade of her father. In short, her public identity lies at the bottom of her root. She can never avoid her reality even if she tries thousand times to avoid. Anyone who will see her must say that she Rosa Burger. Indeed, her given identity and her private world are different.

\section{Rosa's Insight of Fusion of Her Private and Public Life}

Rosa, at last, finds an outlet to be free from her inner anxiety and frustration. She understands that she is going to be a political figure like her father. Hence, her private world declines and she begins to realize her role as a public figure. Booker (1998) argues that "the dialectical 'synthesis' of the book thus involves not only Rosa's ultimate ability to understand that the public and the private can be reconciled, but also Rosa's decision, in the last section of the book, to continue to pursue the ideals espoused by her parents" (p. 142). At first, although she is affected by her father's ideology, she accepts those ideologies at last. Actually Lionel's anti-apartheid behavior combines both modernism and realism in the field of South Africa's internal colonialism. All he wants to do is to bring an end of the racial conflict in his country. Rosa realizes that her father's taking steps to bring equality in the country is his modern thinking of liberalism, but his conflict with the white's censorship in the country is the sociocultural problem which is a public affair of his time. Rosa thinks that she should take her father's dream ahead. She comes to know about the social realism in her country, that is to say, the Black Consciousness.

To comment on the fusion of private and public in Rosa's character, it can be said with Head that "one of the primary ways Gordimer engages with history is in her examination of the way both public history and private individual identities are constructed via "ideological discursive practices"" (p. 142). Rosa's fusion occurs through a conflict within her. She wonders if she allows her father's philosophy, but practically her subjectivity is processed through the development of her age and experience. She understands that "the white have got nothing but their horrible power" (p. 257). They can do what is good for them, but not for others who are ignorant of facilities and privileges. Many people are arrested and detained and some whites are also arrested. When Rosa is arrested by policemen she is thought to be realizing her position in the society. The captain Van Jaarseveld reminds her that "he had known her father well" (p. 366) which seems to have signified that he doubts if Rosa will be like her father. Moreover, she has a contact with the Leftist leaders; attends a 
rally and finally postpones going to exile in France. She becomes what her parents want, that is to say, she becomes Lionel's heir who is putting the latest strategy of the struggle.

In From a Crooked Rib, Farah (1945) also shows a sort of reconciliation of Ebla with Awill. Ebla's sense of being inferior to her husband torments her, but she compromises with her life because she loves life, life with her husband. Ebla does not react strongly at her husband's relationship with a white girl in Italy rather she accepts him when he comes back. Farah exposes in the novel Ebla's disappointment who relentlessly seeks a life partner, but she has to be dependant everywhere. Awill makes a space between them when he says to Ebla that "you know how you were created? Ebla says "from clay like you (p. 162). In fact, Farah's viewpoint is to show the power relation between man and woman and, thus, presents the idea of realism in her novel. The contemporary social condition in Somalia is public in general, while Farah's description of Ebla and her evaluation in the society is modern and private. Ebla's acceptance of Awiil, at the end, complicates her idea of woman's right which is her private opinion. Farah juxtaposes Ebla as private and Awill as public. Therefore, the last line of the novel can be seen as an indication of fusion of both Ebla and Awill.

In fact, Burger's Daughter by Nadine Gordimer (1923) is the ardent example of this fusion of private and public. In this novel she juxtaposes literature and politics and fuses them with each other. She breaks the so-called tradition of literature and presents her works almost like a documentary of some historical events. She creates a story of a girl, Rosa Burger, who is the product of Gordimer's (1923) imagination and at the same time is private, but the political setting in the novel is a pubic matter of her time. In this way, Burger's Daughter is the presentation of not only a good piece of literary work but also an actual political document. Gordimer (1923) can be seen as a follower of Marxist who insists on that literature must reflect the histories of the past. Gordimer wins in this attempt. Booker (1998) argues that "this use of an actual political document sets up a dialectic connection between this real-world pamphlet and the fictional world of Gordimer's novel, breaking down the perceived barrier between politics and literature that exemplifies the separation between public and private" (p. 143). Similarly, Ngugi and Farah also break this barrier between literature and history. Ngugi's (1938) reflects in Devil on the Cross Kenya's internal colonial history through an imaginative story of a young girl, Warringa.

However, his novel, Devil on the Cross signifies the political corruption and the social unrest in Kenya. The author is, vividly, understood to be more historic rather than to be a storyteller in her treatment. Through a close reading, Stephen Clingman (1986) encounters Gordimer connecting her story to the happenings in the past. Clingman addresses,

Not only has she made direct use of basic political and historical texts ... but she also undertook interviews with people connected with Fischer and his times. So the figure of Burger acts as a bridge in the novel between fact and fiction, and past and present, as the methods of the novelist and a more orthodox historian coincide. (p. 172)

Gordimer (1923) describes an actual fact or political document in a story and the reader can easily detect that structure in which the historical events are placed. In fine, Burger's daughter along with Devil on the Cross and From a Crooked Rib is almost like the testament in which the author takes the role of a historian and at the same time a literary artist. All of these works cite the historical account through the imaginative stories. They mix both past events and literary imagination and create a combination of both genres, private and public.

\section{Conclusion}

The novel, Burger's Daughter is the exposure of the relationship between her private and public life. The author's aim in this novel is to focus on the prevailing environment of social injustices and cultural separation. She emphasizes on the aspect of private and public in a single figure. Her main character, Rosa Burger is an embodiment of both private and public. She is 
presented in the novel in her social and political history. Booker observes that "a supporter of the African National Congress, Gordimer (1923) worked tirelessly against the censorship that often prevailed in South Africa, advocating the right to free expression for all citizens of the country, regardless of race" (p. 150). Gordimer (1923) adopts a notion of the cultural life force in the people of her time. Rosa is presented as a revolutionary girl in South Africa, but presenting her as revolutionary, Gordimer (1923) relates her subjectivity to the objective world of apartheid. She is seen to behave subjectively and objectively. Rosa can be psychologically alienated, but there is a purpose.

To divulge the historically disturbed past, she has to take the help of this device, Bildungsroman. She gives Rosa a 'national identity' which is both private and public because she is a girl and also Burger's Daughter. To give some more examples of Bildungsroman, Devil on the Cross and From a Crooker Rib can be referred to. In these two novels, both Ngugi (1938) and Farah (1945) use Bildungsroman to bring forth their ideas. Ngugi (1938) comments on the cultural oppression in Kenya while Farah accuses contemporary gender discrimination in Somali society. In this way, they personalize the impersonal matters in their works and, thus, reconstruct a new literary genre, that is to say, Bildungsroman, a compound of both private and public. Although these three novels are thematically different, all of them share the theme of private life and of public life of their central characters.

\section{References:}

[1] Barrett. S., What I say will not be understood': Intertextuality as a Subversive Force in Nadine Gordimer's Burger's Daughter, E-rea [En ligne], 2(1)(2004), 7, https://doi.org/10.4000/erea.491

[2] Beck. Roger B., History of South Africa, U.S.A: Greenwood Publishing Group, (2000)

[3] Booker. M. Keith., The African Novel in English, Portsmouth: Heinemann, (1998)

[4] Clingman. S., The Novels of Nadine Gordimer: History from the Inside, London: Allen and Unwin, (1986)

[5] Dagnino. A., Transcultural writers and novels in the age of global mobility, West Lafayette, IN: Purdue University Press, (2015)

[6] Dagnino. A., Re-discovering Alessandro Spina's transculture/ality in Te young Maronite, Humanities, 5(2)(2016), 42, https://doi.org/10.3390/h5020042

[7] Dimitriu. I., Ten and now: Nadine Gordimer's Burger's daughter (1979) and No time like the present (2012), Journal of Southern African Studies, 42(6)(2016), 1045-1057, https://doi.org/10.1080/03057070.2016.1247553

[8] Epstein. M., Transculture: A broad way between globalism and multiculturalism, American Journal of Economics \& Sociology, 68(1)(2009), 327-351, https://doi. org/10.1111/j.1536-7150.2008.00626.x

[9] Farah. Nuruddin., From a Crooked Rib, United Kingdom: Penguin Books, (2003)

[10] Gordimer. N., Burger's Daughter, New York: Penguin, (1979)

[11] Gordimer. N., Burger's Daughter, London: Bloomsbury Publishing, (2000)

[12] Halil. K., Travelling the "World Round as Your Navel": Subjectivity in Nadine Gordimer's "Burger's Daughter", ARIEL: A Review of International English Literature, 25(2)(1994), 15. 
[13] Lacan. J., Ecrits: a Selection. (Alan Sheridan, Trans.), London: Rutledge, (Original work published 1966)

[14] Nayar. P.K., Postcolonial Literature: An Introduction, New Delhi: Pearson, (2013)

[15] Servan-Schreiber. Claude., Nadine Gordimer: A White African Against Apartheid. In Nancy Bazin \& Marilyn Seymour (Eds.), Conversations with Nadine Gordimer (pp. 108-121. Jackson: University Press of Mississippi, (1990)

[16] Sturrock. J., Structuralism and Since: From Levi Strauss and Derrida. Oxford: Oxford UP, (1979)

[17] Wa Thiong’o. Ngugi, Devil on the Cross. Johannesburg: Heinemann, (1980) 